\title{
DOD Support of Civil Authorities During No-Notice Complex Catastrophes
}

\author{
by \\ Colonel David Theisen \\ United States Army
}

United States Army War College

Class of 13

\author{
DISTRIBUTION STATEMENT: A \\ Approved for Public Release \\ Distribution is Unlimited
}

This manuscript is submitted in partial fulfillment of the requirements of the Master of Strategic Studies Degree. The views expressed in this student academic research paper are those of the author and do not reflect the official policy or position of the Department of the Army, Department of Defense, or the U.S. Government. 
The U.S. Army War College is accredited by the Commission on Higher Education of the Middle States Association of Colleges and Schools, 3624 Market Street, Philadelphia, PA 19104, (215) 662-5606. The Commission on Higher Education is an institutional accrediting agency recognized by the U.S. Secretary of Education and the Council for Higher Education Accreditation. 


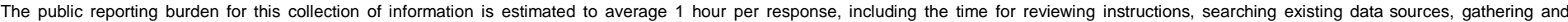

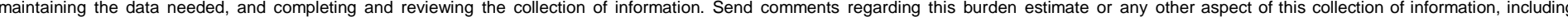

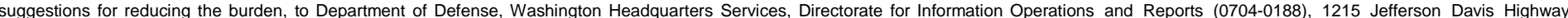

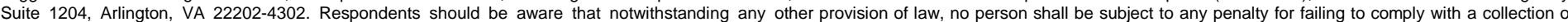
information if it does not display a currently valid OMB control number. PLEASE DO NOT RETURN YOUR FORM TO THE ABOVE ADDRESS.
1. REPORT DATE (DD-MM-YYYY)
2. REPORT TYPE
$\mathrm{XX}-03-13$
STRATEGY RESEARCH PROJECT

4. TITLE AND SUBTITLE

DOD Support of Civil Authorities During No-Notice Complex Catastrophes

3. DATES COVERED (From - To)

5a. CONTRACT NUMBER

5b. GRANT NUMBER

5c. PROGRAM ELEMENT NUMBER

6. AUTHOR(S)

Colonel David Theisen

United States Army

5d. PROJECT NUMBER

5e. TASK NUMBER

5f. WORK UNIT NUMBER

7. PERFORMING ORGANIZATION NAME(S) AND ADDRESS(ES)

Colonel Thomas J. Keegan

8. PERFORMING ORGANIZATION REPORT NUMBER

Center for Strategic Leadership and Development

9. SPONSORING/MONITORING AGENCY NAME(S) AND ADDRESS(ES)

U.S. Army War College

122 Forbes Avenue

Carlisle, PA 17013

10. SPONSOR/MONITOR'S ACRONYM(S)

11. SPONSOR/MONITOR'S REPORT NUMBER(S)

12. DISTRIBUTION / AVAILABILITY STATEMENT

Distribution A: Approved for Public Release. Distribution is Unlimited.

13. SUPPLEMENTARY NOTES

Word Count: 5529

\section{ABSTRACT}

Congress and the civilian leadership have moved a remarkable distance in a short time to evolve to a new paradigm of homeland security and homeland defense. DOD appears slow in adapting to the demands of the future environment. It clings to the security challenges and structure it desires unwilling to leave the comfort of what it has done in the past. DOD needs to accept their new role that congress has defined for them. It has relegated Defense Support to Civil Authorities (DSCA) to a derivative task of their war time mission which leaves little doubt that it will be unable to respond effectively to a no notice complex catastrophe. DOD needs to adapt its force structure to the realities of a post 9/11 environment and create the required structure to meet the DSCA requirements. As part of a national response to complex catastrophes, DOD should consider what changes to National Guard structure would better enable them to perform this role. DOD needs to provide training and resources to support the DSCA missions.

\section{SUBJECT TERMS}

Homeland Security, Natural Disasters, Defense Support of Civil Authorities, FEMA

\begin{tabular}{|l|c|c|c|c|l|}
\hline \multicolumn{2}{|l|}{ 16. SECURITY CLASSIFICATION OF: } & $\begin{array}{l}\text { 17. LIMITATION } \\
\text { OF ABSTRACT }\end{array}$ & 18. NUMBER OF PAGES & 19a. NAME OF RESPONSIBLE PERSON \\
\cline { 1 - 2 } $\begin{array}{c}\text { a. REPORT } \\
\text { UU }\end{array}$ & $\begin{array}{c}\text { b. ABSTRACT } \\
\text { UU }\end{array}$ & $\begin{array}{c}\text { c. THIS PAGE } \\
\text { UU }\end{array}$ & UU & 30 & $\begin{array}{l}\text { 19b. TELEPHONE NUMBER (Include area } \\
\text { code) }\end{array}$ \\
\hline
\end{tabular}



USAWC STRATEGY RESEARCH PROJECT

\title{
DOD Support of Civil Authorities During No-Notice Complex Catastrophes
}

\author{
by \\ Colonel David Theisen \\ United States Army
}

Colonel Thomas J. Keegan

Center for Strategic Leadership and Development

Project Adviser

This manuscript is submitted in partial fulfillment of the requirements of the Master of Strategic Studies Degree. The U.S. Army War College is accredited by the Commission on Higher Education of the Middle States Association of Colleges and Schools, 3624 Market Street, Philadelphia, PA 19104, (215) 662-5606. The Commission on Higher Education is an institutional accrediting agency recognized by the U.S. Secretary of Education and the Council for Higher Education Accreditation.

The views expressed in this student academic research paper are those of the author and do not reflect the official policy or position of the Department of the Army, Department of Defense, or the U.S. Government. 



\begin{tabular}{ll} 
& \multicolumn{1}{c}{ Abstract } \\
Title: & $\begin{array}{l}\text { DOD Support of Civil Authorities During No-Notice Complex } \\
\text { Catastrophes }\end{array}$ \\
Report Date: & March 13 \\
Page Count: & 30 \\
Word Count: & 5529 \\
Key Terms: & $\begin{array}{l}\text { Homeland Security, Natural Disasters, Defense Support of Civil } \\
\text { Authorities, FEMA }\end{array}$ \\
Classification: & Unclassified
\end{tabular}

Congress and the civilian leadership have moved a remarkable distance in a short time to evolve to a new paradigm of homeland security and homeland defense. DOD appears slow in adapting to the demands of the future environment. It clings to the security challenges and structure it desires unwilling to leave the comfort of what it has done in the past. DOD needs to accept their new role that congress has defined for them. It has relegated Defense Support to Civil Authorities (DSCA) to a derivative task of their war time mission which leaves little doubt that it will be unable to respond effectively to a no notice complex catastrophe. DOD needs to adapt its force structure to the realities of a post $9 / 11$ environment and create the required structure to meet the DSCA requirements. As part of a national response to complex catastrophes, DOD should consider what changes to National Guard structure would better enable them to perform this role. DOD needs to provide training and resources to support the DSCA missions. 



\section{DOD Support of Civil Authorities During No-Notice Complex Catastrophes}

The 21 st century is only 12 years old and it is difficult to comprehend the dramatic changes to US security concerns within that small amount of time. It is said that a crisis is too valuable to waste because it is only during these periods of crisis Americans can coalesce from a nation of diverse views into one that is laser focused and speaks with one common voice. ${ }^{1}$ The terrorist attacks of September 11, 2001 fall into this category. These attacks made it clear that there are some people in this world who wish to harm us and are willing to sacrifice themselves in the process. All Americans can recall where they were on Sep 11, 2001 and how their lives changed forever after that date. The American electorate has shown short patience for officials perceived as too slow or unwilling to provide the safety and security that most citizens see as the first duty of a government. These events serve as a fixed point in their lives and mark the first time they ever felt fear in their homes. The nation would begin moving again with a new normal as it adjusted to life with improved security measures. Safety and security are now inextricably entwined and serve as the yardstick by which the public measures the worth of their government.

Increased expectations on DOD demand a new preparedness. The entire national security process and organization has adapted to the new environment, DOD must respond in kind. The time is now for DOD to adjust to the new security demands of supporting catastrophic events in the homeland. Terrorists' attacks of 9/11 and the devastation of Hurricane Katrina generated many studies, commissions, and recommendations. ${ }^{2}$ These improbable BLACK SWAN events are rare but have a high impact on behavior. They demonstrate how the improbable can become possible and force us to reconsider where we may have blind spots in our planning. ${ }^{3}$ Almost every 
change to our domestic security legislation-each reorganization, policy decision, or funding decision dealing with national preparedness- over the last decade is evaluated on how it would improve our ability to prevent or mitigate the effects of one or both of these events. The creation of a cabinet level post, Homeland Security Secretary, oversees a Department of Homeland Security (DHS) with 24 agencies for synchronizing the security of the US homeland. ${ }^{4}$ The Unified Command Plan (UCP) of 2002 was modified by the President to create a geographical combatant commander for North America (US NORTHCOM) responsible for synchronizing US homeland defense. In an era of declining resources, mounting federal debt, and a rebalancing US security policy, there is mounting pressure to ensure that we create the correct correlation of policies and resources to manage risk in the homeland and not lurch from one event to another.

There is a growing suite of missions requiring DOD response and preparedness. All incidents are local but, no-notice complex catastrophes are must plan for events by DOD. The Department of Defense has not yet fully defined and categorized these unexpected catastrophic events or its approach to dealing with them. DOD is currently using 'catastrophic events' as an interim definition. ${ }^{5}$ The Joint Publication defines this as "any natural or man-made incident, including terrorism, which results in extraordinary levels of mass casualties, damage, or disruption severely affecting the population, infrastructure, environment, national morale, and/or government functions". The Government Accounting Office (GAO) used the term "catastrophic natural disaster" to describe Hurricane Katrina. ${ }^{6}$ Congress has used similar terms in guiding much of the reshaping of the National Security structure to counter threats to security and the defense of the US homeland. DOD has been focused in fighting the Global War on 
Terror. Now, as the second war in the past decade winds down in Afghanistan, DOD should be looking at the security environment and crafting its future force. Earthquakes that impact a population of 10 million people or the detonation of a 10 kiloton nuclear device would clearly require a DOD response based on the amount support required. The civilian guidance for Hurricane SANDY is a clear insight into future complex catastrophes in that DOD is expected to "Go Big, Go Fast, and Go Smart" in supporting civilian authorities. $^{7}$

In order to respond to increased expectations and a growing suite of missions for the US military, DOD must chart a way forward to insure success. This paper focuses on ways DOD can prepare to respond to no notice complex catastrophes. It excludes portions that would be worthy of papers themselves such as Cyber events, support provided under title 31 USC (Economy Act), and infrastructure resilience. In reviewing the required capabilities for support of civil authorities, it is clear the majority of the assets are located in the Army. They are geographically and organizationally dispersed through the Active Army, National Guard, and the Army Reserve. Events requiring defense support to civilian authorities are politically charged rescue operations that require speed, mountains of logistics, and communications delivered in a coordinated manner. We can do this by establishing the correct organization, force structure, and training programs to prepare for these new no-fail missions.

\section{DSCA Strategic Environment}

The 10th Amendment to the US Constitution as part of the Bill of Rights states "The powers not delegated to the United States by the Constitution, nor prohibited by it to the States, are reserved to the States respectively, or to the people". Local authorities 
are responsible for the running of states and counties at the local level. Over the last 225 years the federal government has remained aloof and adopted a laissez faire approach to meddling in the affairs of states. Tensions are created between state and federal government as the local authorities begin shifting from normal to emergency operations in catastrophes. The federal government is prepared to support but state situational awareness degrades quickly in complex catastrophes. Governors may not realize the support required locally and how the President is viewed nationally if he is perceived as slow to respond. This tension between state and federal responsibilities for security and defense has generated periodic legislation from congress. These incremental legislative changes assigned roles and responsibilities for incidents or events at the state and federal level. The Insurrection Act of 1807, The Posse Comitatus Act of 1878 and The Stafford Act of 1974 are the three most prominent legislative changes of these roles. ${ }^{8}$

The Stafford Act of 1974 defines the conditions and the process by which the president may render federal assistance. There are three categories of assistance, fire management assistance, emergency declarations, and major disaster declarations. Fire assistance is normally approved by the regional FEMA administrator. Emergency and major disaster declarations require the President's approval. All require a formal request for assistance from the governor before any assistance can be approved. The exception to this rule is for cases where the President "determines that an emergency exists for which the primary responsibility for response rests with the United States because the emergency involves a subject area for which the constitution or laws of the United States exercise exclusive or preeminent responsibility and authority". ${ }^{9}$ The 
bombing of the Murrah Federal building in Oklahoma City on 19 April 1995 is an example of a federal response declaration.

There are a number of funds that are available to FEMA under the Stafford Act to be a bridge for the state to conduct relief operations. Most of these are pulled into motion after the event. Hurricanes and flood events create a smaller category of emergency declarations that allow expenditure of resources and funds to reduce the damage and loss of life. A mandatory evacuation of areas in the expected landfall of a hurricane is one such example. The evacuation of nursing homes and other care facilities of patients that may be adversely affected by loss of power is another example.

The Posse Comitatus Act of 1878 is probably the least understood of the three laws. It was passed as part of an Army appropriations bill in 1877 and was amended to include the Air Force in 1956. With the passage in 1878 of the Posse Comitatus Act, Congress, Southern States, and the Army, all three entities interpreted the act to protect their own interests and use it as an excuse to keep from changing the status quo. DOD continues to interpret the act in the most severe way, even directing that it applies to the Navy and Marines despite the fact it was never intended to be used to limit their abilities to support law enforcement. DOD policy for the Navy and Marines to adhere to the Posse Comitatus Act is consistent with their desire not to change. ${ }^{10}$

Analysis of Changes in the Government Post 9/11

Congress dramatically changed the role of government in homeland security and defense after 9/11. The PATRIOT Act of 2001 enhanced border security and reformed the process of how intelligence was shared. They would later strengthen intelligence sharing in 2004. The Intel Reform and Terrorism Prevention Act of 2004 created a 
Director of National Intelligence to coordinate the work of 15 federal intelligence agencies. This act would also create a National Counter Terrorism Center (NCTC) to analyze intelligence information. ${ }^{11}$

Congress wants a national approach to homeland security. They created a cabinet level secretary to lead the new Department of Homeland Security (DHS) with Homeland Security Act of 2002. This department realigned 29 agencies under one department in the largest government reorganization since 1947. ${ }^{12}$ The national responsibility for homeland security is centralized in DHS. Air travel security was a particular concern after the 9/11 attacks. Congress created the Transportation Security Agency (TSA) to assume responsibility for the security of passengers for a vast network of domestic and international flights ${ }^{13}$.

Congress was appalled with the dysfunctional process of emergency preparedness and disaster relief that was demonstrated during Hurricane KATRINA in 2005. FEMA was designated as regional lead agency in a national response to all disasters. While this slow moving storm allowed for the ability to move resources and evacuate populations before landfall, the failure of the response effort to save lives and protect property played out for almost three weeks on national television. Congress was swift after this debacle in creating the Post-Katrina Emergency Management Reform Act of 2006 (PKEMRA). Most local emergency management processes were not scalable and hampered the ability to reinforce the initial response efforts with additional resources. This legislation further defined a national response approach and established new leadership positions in FEMA. The act enhanced the agency's authority by directing the FEMA Administrator to have responsibility for coordinating a 
broad range of activities before and after disasters occur. ${ }^{14}$ Congress has been quite clear in the changes legislated in our national security structure that the federal government will never again be caught unprepared to respond to a catastrophe. There is a clear expectation that DOD will be prepared and ready to support states before they are overwhelmed.

Evolutions in Policy

The Executive Branch and federal agencies quickly developed new policy to implement the reforms directed by Congress. Many of the sweeping changes were issued in Homeland Security Policy Directive -5 (HSPD-5). Using the congressional desire for a national approach to homeland security, DHS defined its over-arching policy for emergency response to incidents and its national preparedness goals. DHS used the integration of federal with state and local emergency managers to create a seamless national response program for security and disaster response. ${ }^{15}$ This coordinated National Response Framework (NRF) defines roles and responsibilities as well as the common language of emergency management for a national response program. The National Incident Management System (NIMS) allows a national approach using the collective resources available at all levels. ${ }^{16}$

Presidential Policy Directive 8 (PPD-8) is intended to galvanize action by the federal government; it is also the center of facilitating an all-of-nation approach to emergency preparedness. President Obama has recognized the need for a national approach that looks across a broader range of prevention and mitigation instead of simply responding to homeland security incidents. PPD-8 declares that national preparedness is a shared responsibility of all levels of government, the private and 
nonprofit sectors, and individual citizens. PPD-8 establishes 5 National Planning Frameworks (NPF), identifies an Interagency Policy Committee (IPC) of the National Security Council, and provides definitions for each of the planning frameworks in the key terms of Prevention, Protection, Mitigation, Response, and Recovery that generates the national policy for each of the IPC. ${ }^{17}$ This national approach is the catalyst for a program that seeks to reduce the impact of catastrophes before the incident through preparation of the infrastructure and planning the response. PPD-8 recognizes the tensions that exist between the federal and states powers and seeks to remove this friction by defining roles, responsibilities, and training and removing many of the unknowns before the catastrophe. DOD is a member of 3 of these NPFs and needs to shape the development of these frameworks in concert with DOD's plan to support civil authorities.

Interoperability Reforms

The movement of the US Coast Guard to the DHS because of congressional reform creates a powerful model in encouraging interoperability. The Coast Guard was the savior for many Americans during Hurricane Katrina who were trapped in flooded New Orleans. While the US Coast Guard had planned for restoring navigation and environmental clean up after KATRINA, their versatility enabled them also to play a pivotal role in the rescue of over 35,000 of the 60,000 Americans trapped in flooded New Orleans. ${ }^{18}$ Since the Coast Guard's integration as regular part of the homeland security system, they have developed a great deal of flexibility. Their success is directly tied to the ability to the ability to plan, organize, equip, and train as part of the DHS. The Coast Guard responded with 4000 personnel to KATRINA, executed all their 
maritime tasks, and became the first responder of choice because of the speed and efficiency of the operations while the National Guard and Title 10 response forces both struggled with the unknowns of supporting civilian authorities on a massive scale for the first time.

Another outstanding example of enhancing interoperability for DSCA through organizational design is the establishment of US NORTHCOM as the geographical combatant commander for North America. In partnership with DHS, this new DOD headquarters shares joint responsibility to provide for "the safety, security, and resilience of the homeland and the American people." ${ }^{19}$ US NORTHCOM developed, in concert with DHS, 15 planning scenarios that defined the types of incidents that should be used to plan responses in the homeland. Most of the incidents listed are directly related to security tasks, but two are no-notice complex catastrophes: the detonation of a 10 kiloton nuclear device in the US homeland, and a 7.7 magnitude earthquake affecting an area populated by 10 million people. Both no-notice scenarios strain the national response resources and are a race against time to save lives.

The USCG set the standard for a federal response with its valuable contributions during its Hurricane Katrina rescue operations. US NORTHCOM's ability to remove the cumbersome Mission Assignment (MA) process to speed up their support of Hurricane Sandy was a result of their training. Exercises with trained personnel are the foundation of DOD ability to be unmatched on the modern battlefield. Our security in the homeland depends on DOD to be equally skilled and trained in their support of no-notice complex catastrophes. 
Impact of the Changes on National Military Strategy

DOD appears poised to finally react to the increased expectations and implied missions that have evolved over the last 10 years. First, on the strategic front, we are reaching the end of the war in Afghanistan and our policy for employing military force appears likely to follow the Libyan or Mali model of "leading from behind". ${ }^{20}$ Second, following the glowing success of the Federal response to Hurricane Sandy, many of DOD's implied tasks are now specified and we will likely “Go Big, Go Early, and Go Smart" when disaster threatens our citizens.

Recent guidance from OSD has clarified the way forward but has done little to generate the necessary change in mindset that DSCA is simply a derivative of other missions. The Secretary of Defense has issued guidance on Improving Defense Support in Complex Catastrophes. ${ }^{21}$ Other recent directives have defined the Immediate Response Authority and the Emergency Authorities criteria that DOD Commanders should use to provide support during catastrophes. Discrete changes have been made to create a CBRN response element but there have been no other appreciable changes to structure or training. Most post-conflict studies on structure attempt to identify over strength and under strength capabilities. ${ }^{22}$ Each state has a WMD-CST (Weapon of Mass Destruction- Civil Support Team), and three states have an additional CST. These 1050 Soldiers represent the only full time DSCA support and in most states, the only subject matter expertise to analyze and advise civilian leaders on CBRN identification. ${ }^{23}$ By comparison, the total Army has 105 bands (33 Active, 18 Reserve and 54 National Guard) for purely ceremonial purposes. ${ }^{24}$ The USCG has adapted its entire organization to work within the umbrella of security related agencies in DHS in a 
seamless manner. US NORTHCOM has shaped its structure and training, and enables much of the regional planning for the emergency management operations coordinated by FEMA. Other portions of DOD need to accept the DSCA mission and adapt their organizations to the higher expectations that accompany this new mission.

Perhaps we need to consider new roles for the National Guard and Army Reserve to meet the DODs mission of responding to catastrophes. These units are located throughout the homeland, and possess the assets or have agreements with other states to generate the support required for a state emergency. They will in all cases be the first responders who arrive to support the initial local fire and police personnel. In a no-notice complex catastrophe, the entire nation must be ready for these events. A well known fact in emergency management circles is that most lives are saved in the first 72 hours of the disaster. Since many of the DSCA implied missions for $\mathrm{DOD}$ are rapidly evolving into specified tasks, a top priority should be to review capabilities by location. In evaluating the security requirements of a post $9 / 11$ environment, DOD can better describe the role of the Active duty, National Guard, and Reserve forces to better align structure and missions to mitigate risk in the homeland.

The 2014 Quadrennial Defense Review (QDR) is the best opportunity for DOD to articulate its understanding of support requirements for the homeland and the vital role of the Army Reserve and National Guard in providing that support. DOD needs to define its new role and how its force structure will change to support these new requirements. Changes in DOD structure are inherently a political process because of the economic impact of force structure and its location. The 2010 Quadrennial Defense Review (QDR) simply lists existing force structure and the levels that the budget can 
support ${ }^{25}$. It is not a document with a 20 year vision. Congress, in PL 108-375 The Ronald Reagan Defense act of 2005, directed a Commission to study Transformation of the National Guard and Reserves (CNGR) ${ }^{26}$ The commission provided a list of 96 recommendations that enables DOD to shape the 2014 QDR to address the implementation of these recommendations. In concert with Congress, DOD can better align its structure and remove some of the current perverse incentives to future changes by resourcing the National Guard and Army Reserve to train for DSCA missions instead of solely being a Strategic Reserve.

\section{Strategic Way Ahead}

\section{DOD Needs to Accept the DSCA Mission}

Defense Support of Civilian Authorities is unlike any other mission DOD must execute on behalf of the nation. When a catastrophe overwhelms local response capabilities, the Federal response must get it right the first time. These are political events where success is measured in terms that military organizations are ill equipped to handle without training. While this is defined as a homeland defense task, the reality is that with small exceptions it is homeland security support. There is no near peer competitor threatening the US homeland with conventional forces. If deterrence fails, only DOD has the resources to respond to a WMD event in the homeland. DOD, and in particular the Army, needs to accept the mission of support to civilian authorities and review its doctrine, manning, equipping, and training strategy for the future that is more in line with the demonstrated desires of our civilian leaders. Congress is determined to never be surprised in the homeland. The American Public is watching the new security environment with much higher expectations of the federal government to respond swiftly 
and decisively to support civilian authorities during catastrophes. DOD's motto of "Go Big, Go Fast, and Go Smart"27 works for a predictable catastrophes such as hurricanes. It is useless for no-notice events unless you have developed the plans, built flexible structure, and trained as part of the national response.

\section{DOD Needs to Restructure its Forces}

The Army needs to evaluate its current structure based on future environments and not its comfort zone. DOD, and the Army in particular, are ill structured to execute all of its assigned post OIF/OEF tasks. Poor decisions in a period of declining resources will further degrade their ability to accomplish DSCA missions. This evaluation will be in concert with Congress since the Army, the National Guard, and the US Army Reserve structure changes are a political decision. Congress will ultimately decide on how much risk is acceptable and how much change the nation can afford.

Design the National Guard and Army Reserve structure as the lead for DOD in a national response to complex catastrophes. Every incident is local until it requires additional support. The National Guard response will shape the regional support plan before Title 10 forces arrive as part of a national response to a no-notice complex catastrophe. The Army National Guard has some 360,000 members spread out through 50 states, and 3 territories. The only purpose-built units for DSCA are in the National Guard. Since the National Guard has 8 Infantry divisions with only 1 National Guard division headquarters deploying over the last decade, it is more efficient to reallocate this structure to support capabilities that are required by the regional planning scenarios. 
DSCA is the future environmental threat we have not considered in the ARFORGEN model. Use of the Army Reserve forces as the strategic reserve force needed for the homeland would dramatically reduce risk and greatly improve effectiveness for DOD to respond. The Army Reserve was created just prior to WWI to generate the medical capabilities required by a modern Army and has about 205,000 pers. CSA Creighton Abrams outlined the total Army concept that aligned capabilities strategically under the Army, the National Guard, and the Army Reserve as a total force at the end of the Vietnam War. If a unit type did not deploy to OIF or OEF over the last decade, it is probably even less relevant in the future environment described in the NSS. There is a narrow window to make informed decisions about structure based on changes in policy and the future environment. The Army Reserve provides the majority of our medical, engineering, aviation, military police, civil affairs, and CBRN units to the total force. There are five Training Divisions in the Army Reserve designed to train a large conscripted Army for war. With the all volunteer force, this is no longer a national priority. With a volunteer force and a light foot print, it is time to re-mission these organizations to cover the training gaps in DSCA. The Army Reserves also provide some theater level headquarters that were not fully used over the last decade. Remission some of the Army Reserve Engineer, Military Police, CBRN and Logistics commands as Two Star Headquarters to provide much of the high demand capability in a complex catastrophe. The geographic dispersion and resident skills available affords an opportunity to shape these into regional response headquarters for DSCA tied to existing FEMA regions. 


\section{DOD Needs to Train for DSCA Operations}

US NORTHCOM has developed the DSCA environment for DOD. The 15 national planning scenarios describe the broad range of incidents. DOD's focus should be on providing trained and ready forces to respond to these incidents. All but two of the scenarios could be met with DODs current array of units. The two no-notice complex catastrophes of a 10 Kiloton nuclear detonation and devastating earthquake are the two black swan events that will overwhelm a regional response. Since Congress is determined never to be surprised again in the homeland, DOD needs to man, equip, and train forces for these two urgent no-notice catastrophes. Because expectations are elevated and many missions are moving from implied tasks to specified roles, if DOD does not embrace their new role, there will be tension.

US NORTHCOM has a significant training challenge in order to be able to integrate untrained DOD elements into DSCA operations. CDR US NORTHCOM is charged with responsibility for three specific tasks. ${ }^{28}$

- Support to Civil authorities at the federal, state, tribal and local level.

- Pandemic Influenza and Infectious Diseases (PI\&ID) - Synchronizes DOD planning efforts in support of US Government response to PI\&ID.

- Chemical Biological Radiological Nuclear and High Yield Explosive Consequence Management (CBRNE-CM)

There is a direct correlation between these specific responsibilities and the requirement to support the 15 base planning scenarios developed with DHS. The perception that DSCA missions do not require focused and specific training to insure success exacerbates the level of risk we accept during a response. While US NORTHCOM and 
National Guard have created a Dual Status Commander construct that synchronizes the efforts of state and federal forces, it is cumbersome unless practiced on a regional and routine basis.

Current expectations that DOD will "Go Big, Go fast and Go Smart" ${ }^{29}$ require military forces be ready nearly instantaneously when thousands and possibly hundreds of thousands of lives may be at stake. During KATRINA, the USCG demonstrated the value of training as a key factor in dealing with no-notice catastrophes. Only DOD possesses many of the key resources required to support operations in a major earthquake. If a 7.7 magnitude earthquake occurred in the central US, the damage caused by this no-notice event is staggering. There is a cascading effect as infrastructure collapses that renders other capabilities unusable and only DOD can restore some of the systems to operate in those conditions. Damage estimates of a 7.7 seismic event in along the New Madrid seismic zone includes 8 states, 140 counties, and three FEMA regions; 700,000 buildings damaged, 130 major hospitals damaged, 15 major bridges damaged and over 2 million households without electrical power. ${ }^{30}$ Casualties for this event are estimated at 86,000 killed and injured, 7.5 Million people displaced and another 2 million households seeking temporary shelter. It is estimated that it will require 42,000 personnel to conduct search and rescue at 1500 locations. Demands for emergency services, power, natural gas, and shelter will be critical and interruptions into a national economic distribution system will quickly surface. DOD will need to respond rapidly and start generating critical capabilities desired by civil authorities within hours. DOD will be challenged to identify the capabilities, alert, and move them to the area. ${ }^{31}$ Sustainment of the population and the responding DOD 
forces in the affected area will be a critical task. ${ }^{32}$ Synchronizing actions with local, state and federal partners will be a key to insure effective use of critical resources. Portions of the local, state and federal capabilities will be victims of the earthquake and not be able to respond as effectively as planned. All of these events are not normal tasks for DOD. Leaders, staffs organizations need to be trained in how to support civil authorities. DOD capabilities require the equipment and trained personnel to operate them be formed as units in the response. A catastrophe like this will be of strategic national consequence that will eclipse KATRINA and the expectation and tasks to DOD are clear. But it remains untrained and ill prepared to execute.

Response to Pandemic Influenza and Infectious Diseases (PI\&ID) incident is challenging for US NORTHCOM. 5 of the 15 National planning scenarios are PI\&ID events. Each response is tailored to the PI\&ID once it is identified but this may be well after the initial response has started. There are a number of public health organizations at the local, state, and federal level that track infectious diseases. CDR NORTHCOM is called to synchronize DOD response with assets that are unfamiliar with the civilian support systems. Most of the military medical units are familiar with the civilian medical systems because of consistent cross training but the much larger general support forces that is required for the overall support of logistics, evacuation, communications and support activities are untrained in DSCA operations.

CBRN incident response requires rapid synchronization with local, state, and federal partners to effectively use resources. The nature and complexity of the third mission to respond to and support a CBRN event clearly requires training and a tremendous amount of logistical support. DOD has spent considerable time and effort 
to generate a manned, equipped, and trained force of specialists to cope with CBRN events; it has failed to generate the greater relief operations capability that is required for the area outside of the immediate effects of the $10 \mathrm{KT}$. Downwind hazards, casualties, and displaced persons generated by this event will quickly dwarf the capabilities of surrounding cities and states because of the amount of population affected. Key infrastructure and personnel will become contaminated by an inability to screen casualties. This will be an event of national strategic consequence that is compounded by the fact it was an attack

A 10 kiloton nuclear device in a populated city is the worst case scenario from the 15 national planning scenarios. The effects of this event in a populated region will cause large numbers of dead and wounded. Search and Rescue teams, decontamination teams, and communications suites will be first priorities on any response. DOD will be challenged to identify the capabilities, alert, and move them to the area on such a no notice event without prior training of these units. Sustainment of the population and DOD forces in the affected area will be a critical task. Portions of the local, state, and federal capabilities will be victims of the attack and not be able to respond effectively. Regional forces will respond but will quickly exhaust their resources because in these events almost every form of infrastructure is inoperable or has collapsed under the surge in requirements. Availability of food, water, medical supplies, fuel, and protective gear will be the limiting factors in the success of the response. 


\section{Conclusion}

Congress and the civilian leadership have moved a remarkable distance in a short time to evolve to a new paradigm of homeland security and homeland defense. DOD appears slow in adapting to the demands of the future environment. It clings to the security challenges and structure it desires, unwilling to leave the comfort of what it has done in the past. Consensus for changes to DOD structure is apparent and there is a narrow window of opportunity to outline the requirements of the force for the future environment. The 2014 QDR is an ideal opportunity to address each mission given to DOD and reevaluate what is actually required to execute.

DOD needs to accept the new role that congress has defined for them. It has relegated DSCA to a derivative task of their war time mission which leaves little doubt that it will be unable to respond effectively to a no-notice complex catastrophe. DOD needs to adapt its force structure to the realities of a post 9/11 environment and create the needed structure to meet the DSCA requirements. As part of a national response to complex catastrophes, DOD should consider what changes to National Guard structure would better enable them to perform this role. DOD also needs to provide training and resources to support the DSCA missions.

\section{Endnotes}

${ }^{1}$ Rahm Emanuel Opportunities of Crisis, Wall Street Journal Digital Network, 19 Nov, 2008."YouTube video file, http://www.youtube.com/watch?v= mzcbxi1Tkk (accessed Feb 28, 2013)

2 Donald Rumsfeld, Richard Meyer "Special Briefing on the Unified Command Plan", news transcript, Defense link, April17, 2002.

http://www.thefreelibrary.com/New+challenges+for=the=unified=command=plan.=\%28Military... a099817513 (accessed Mar 2, 2013)

${ }^{3}$ Nassim Nicholas Taleb, "The Black Swan: The impact of the Highly Improbable " New York Times, April 22, 2007 
${ }^{4}$ Homeland Security Act of 2002, Public Law 296, $107^{\text {th }}$ Cong, $2^{\text {nd }}$ sess. (Nov 25, 2002), 8.

${ }^{5}$ Leon Panetta, Secretary of Defense Memorandum, Actions to Improve Defense Support in Complex Catastrophes, OSD007796-July 12, 2012.

${ }^{6}$ US Government Accountability Office, Coast Guard - Observations on the Preparation, Response and Recovery mission related to Hurricane Katrina. (Washington, DC. US Government Accountability Office, July 2006) 1.

${ }^{7}$ DR Paul Stockton, "OSD After Action Review- Hurricane Sandy" briefing slides with notes. Pentagon, Washington DC, Dec 20, 2012

${ }^{8}$ Bruce R Lindsay, Francis X. McCarthy, Stafford Act Declarations 1953-2011: Trends and Analysis and Implications for Congress. ( Washington DC: U.S. Library of Congress, Congressional Research Service, Aug 31, 2012) 2.

${ }^{9}$ Francis X. McCarthy, Stafford Act Disaster Assistance: Presidential Declarations, Eligible Activities, and Funding (Washington DC: U.S. Library of Congress, Congressional Research Service, June 7, 2011) 1.

${ }^{10}$ William J Lynn III, Defense Support of Civil Authorities ( DSCA), DOD Policy Directive 3025.18 with change 1 , (1September 21, 2012)

${ }^{11}$ USA PATRIOT ACT, Public Law 56, $107^{\text {th }}$ Cong., $1^{\text {st }}$ sess.)Oct 25,2001$) 6,72$.

${ }^{12}$ Intelligence Reform and Terrorism Protection Act, Public Law 458, $108^{\text {th }}$ Cong., 1 st sess. (Dec 12, 2004), 7.

${ }^{13}$ Aviation and Transportation Security Act, Public Law $71,107^{\text {th }}$ Cong., $1^{\text {st }}$ Sess. (Nov 19, 2001), 1.

${ }^{14}$ McCarthy, "Stafford Act," 3.

${ }^{15}$ George W. Bush, Homeland Security Presidential Directive/HSPD-5, Management of Domestic Incidents (Washington, DC. The White House, February 28, 2013) http://www.fas.org/irp/offdocs/nspd/hspd-5.hmtl (accessed Mar 3, 2013)

${ }^{16}$ Jena Baker McNeill, Matt A. Mayer, "Two Steps Backward: Homeland Security Presidential Policy Directive -8," April 14, 2011, http://www.heritage.org/research/reports/2011/04/two-steps-backward-homeland-securityspresidential-policy-directive-8 (accessed Mar 3 2013)

${ }^{17}$ Jared T. Brown, Presidential Policy Directive 8 and the National Preparedness System: Background and Issues for Congress (Washington DC: U.S. Library of Congress, Congressional Research Service, Oct 21, 2011) 1.

${ }^{18}$ US. Government Accountability Office, Coast Guard, 3.

${ }^{19}$ Tech Sgt Thomas J Doscher, DHS Director of Operations to USNORTHCOM: We're with You, NORAD and NORTHCOM Public Affairs, Feb 10, 2012 
${ }^{20}$ Ryna Lizza, The Consequentialist: How the Arab Spring remade Obama's foreign policy", New Yorker, May 2011, 10.

${ }^{21}$ Panetta, " Actions to Improve, "

22 John J. McGraff, The Other End of the Spear: Tooth to Tail Ratio ( T3R) in Modern Military Operations" ( Fort Leavenworth, KS: Combat Studies Institute Press 2007) 86.

${ }^{23}$ Paul McHale, Critical Mismatch: The Dangerous Gap Between Rhetoric and Readiness in DOD's Civil Support Mission ( Washington DC, Heritage Foundation, Aug 23, 2013)

${ }^{24}$ John T. Bennet, Analyst: Military Bands Cost the Pentagon $\$ 50$ B over the next 50 years. The Hill Global Affairs Blog, May 18, 2011, http://thehill.com/homenews/administration/161837analyst-military-bands-to-cost-dod-50b-in-50-years ( accessed Mar 3, 2013)

${ }^{25}$ Stephen Daggett, Quadrennial Defense Review 2010: Overview and Implications for National Defense Planning, (Washington DC: U.S. Library of Congress, Congressional Research Service, May 17, 2010) 33.

${ }^{26}$ Commission on The National Guard and Reserves: Transforming the National Guard and Reserves into a $21^{\text {st }}$ Century Operational Force. Final report to Congress Jan 31, 2008

27 DR Paul Stockton, "OSD After Action Review,"

28 Barack Obama, Unified Command Plan 2011, (Washington, DC: The White House, Sep , 2011)

${ }^{29}$ DR Paul Stockton, "OSD After Action Review, “

${ }^{30}$ Impact of New Madrid Seismic Zone Earthquakes on the Central US- Vol 1 Report number 09-03 October 2009. vii.

${ }^{31}$ USNORTHCOM COMMANDERS Estimate for Defense Support of Civil Authorities in Complex Catastrophes. (Draft) 30 Oct 2012, 5.

${ }^{32}$ Ibid 
